Supporting Information

\title{
On the electrochemical phase evolution of anti-PbO type CoSe in alkali ion batteries
}

Conrad H. R. Gillarda, Xiuquan Zhou ${ }^{b}$, Maxim Avdeeve,d, Efrain E Rodriguez ${ }^{b}$, Neeraj Sharmaa,

aSchool of Chemistry, University of New South Wales, Sydney, NSW 2052, Australia

${ }^{b}$ Department of Chemistry and Biochemistry, University of Maryland, College Park, Maryland 20742, United States

'Australian Nuclear Science and Technology Organisation, Kirrawee DC, NSW 2232, Australia

${ }^{d}$ School of Chemistry, The University of Sydney, Sydney, NSW 2006, Australia 


\section{S1: Rietveld refinement model parameters}

It should be noted that the weight fractions in the below tables differ from those presented in the main paper, as they include all species including electrochemically inactive materials such as carbon black. These were excluded for clarity in the main text.

Table S1: Rietveld refinement model parameters for CoSe versus Li ex-situ experiments. Abbreviations used are as follows. CoSe Hex: Hexagonal CoSe. CoSe Tetr: Tetragonal CoSe. a,b,c: Crystallographic Lattice parameters. wR: Weighted Residual.

\begin{tabular}{|c|c|c|c|c|c|c|c|c|c|c|c|c|c|c|c|c|c|c|c|c|c|c|c|c|}
\hline & $\begin{array}{l}\text { CoSe } \\
\text { Hex } \\
\mathrm{a}(\AA ̊) \\
\end{array}$ & \begin{tabular}{|l} 
CoSe \\
Hex \\
b (Å) \\
\end{tabular} & \begin{tabular}{|l} 
CoSe \\
Hex \\
c (Å) \\
\end{tabular} & \begin{tabular}{|l|} 
CoSe \\
Hex \\
Phase \\
Fraction \\
\end{tabular} & $\begin{array}{l}\text { CoSe } \\
\text { Tetr } \\
\text { a (A) } \\
\end{array}$ & $\begin{array}{l}\text { CoSe } \\
\text { Tetr } \\
\text { b (Å) } \\
\end{array}$ & $\begin{array}{l}\text { CoSe } \\
\text { Tetr } \\
\text { c (A) } \\
\end{array}$ & \begin{tabular}{|l|} 
CoSe \\
Tetr \\
Phase \\
Fraction \\
\end{tabular} & \begin{tabular}{|l} 
March- \\
Dollase \\
Ratio \\
\end{tabular} & Axis & $\begin{array}{l}\mathrm{Li}_{1} \mathrm{CO}_{2} \mathrm{Se}_{2} \\
\mathrm{a}(\AA \mathrm{A}) \\
\end{array}$ & $\begin{array}{l}\mathrm{Li}_{\mathrm{x}} \mathrm{Co}_{2} \mathrm{Se}_{2} \\
\mathrm{~b}(\AA)\end{array}$ & $\begin{array}{l}\mathrm{Li}_{x} \mathrm{Co}_{2} \mathrm{Se}_{2} \\
c(\AA) \\
\end{array}$ & $\begin{array}{l}\mathrm{Li}_{x} \mathrm{CO}_{2} \mathrm{Se}_{2} \\
\text { Phase } \\
\text { Fraction }\end{array}$ & \begin{tabular}{|l|} 
March- \\
Dollase \\
Ratio \\
\end{tabular} & Axis & $\begin{array}{l}\text { Li }{ }_{2} \mathrm{Se} \text { a, } \\
\mathrm{b}, \mathrm{c}(\AA)\end{array}$ & \begin{tabular}{|l|}
$\mathrm{Li}_{2} \mathrm{Se}$ \\
Phase \\
Fraction
\end{tabular} & $\begin{array}{l}\text { Co } \\
\text { a (Å) }\end{array}$ & $\begin{array}{l}\text { Co } \\
\text { b (Å) }\end{array}$ & $\begin{array}{l}\text { Co } \\
\text { c (Å) }\end{array}$ & \begin{tabular}{|l|} 
Co \\
Phase \\
Fraction \\
\end{tabular} & $\begin{array}{l}\text { Overall } \\
\text { wR }\end{array}$ & \begin{tabular}{|l} 
Zero \\
Offset
\end{tabular} \\
\hline Parent & $3.599(7)$ & $3.599(7)$ & $5.280(8)$ & $0.230(1)$ & $3.712(2)$ & $3.712(2)$ & $5.330(3)$ & $0.770(1)$ & 0.6607 & '001 & & & & & & & & & & & & & $2.96 \%$ & -0.00952 \\
\hline $3 \%$ & $3.601(4)$ & $3.601(4)$ & $5.282(5)$ & $0.328(8)$ & $3.709(2)$ & $3.709(2)$ & $5.337(2)$ & $0.672(8)$ & 0.515 & '001 & & & & & & & & & & & & & $2.46 \%$ & 0.002225 \\
\hline $7.50 \%$ & $3.610(7)$ & $3.610(7)$ & $5.27(1)$ & $0.300(1)$ & $3.657(4)$ & $3.657(4)$ & $5.373(4)$ & $0.350(3)$ & 0.6011 & |'001 & $3.695(5)$ & $3.695(5)$ & $5.509(4)$ & $0.360(3)$ & 0.5121 & '001 & & & & & & & $2.71 \%$ & -0.04581 \\
\hline $20 \%$ & 3.65(1) & $3.65(1)$ & $5.230(8)$ & $0.390(1)$ & $3.687(6)$ & $3.687(6)$ & $5.383(8)$ & $0.350(2)$ & 0.6421 & '001 & $3.73(1)$ & 3.73(1) & $5.605(9)$ & $0.260(2)$ & 0.5109 & '001 & & & & & & & $2.65 \%$ & -0.04218 \\
\hline $60 \%$ & & & & & & & & & & & & & & & & & $6.003(8)$ & 1.00 & & & & & $6.59 \%$ & -0.082 \\
\hline $100 \%$ & & & & & & & & & & & & & & & & & $6.014(4)$ & $0.66(1)$ & $2.513(6)$ & $2.513(6)$ & $4.08(1)$ & $0.34(1)$ & $2.03 \%$ & 0.063981 \\
\hline
\end{tabular}


Table S2: Rietveld refinement model parameters for CoSe versus K ex-situ experiments. Abbreviations used are as follows. CoSe Hex: Hexagonal CoSe. CoSe Tetr: Tetragonal CoSe. a,b,c: Crystallographic Lattice parameters. wR: Weighted Residual.

\begin{tabular}{|c|c|c|c|c|c|c|c|c|c|c|c|c|c|c|c|c|c|c|c|c|c|c|c|c|c|c|}
\hline & $\begin{array}{l}\text { CoSe } \\
\text { Tetr } \\
\text { a, b (Å) }\end{array}$ & $\begin{array}{l}\text { CoSe } \\
\text { Tetr } \\
\text { c (Å) }\end{array}$ & \begin{tabular}{|l} 
CoSe \\
Phase \\
Fraction
\end{tabular} & $\begin{array}{l}\text { March- } \\
\text { Dollase } \\
\text { Ratio }\end{array}$ & Axis & $\begin{array}{l}\text { CoSe } \\
\mathrm{Hex} \\
\mathrm{a}, \mathrm{b}(\AA)\end{array}$ & $\begin{array}{l}\text { CoSe } \\
\text { Hex } \\
c(\AA \AA)\end{array}$ & \begin{tabular}{|l|} 
CoSe \\
Hex \\
Phase \\
Fraction \\
\end{tabular} & $\begin{array}{l}\mathrm{K}_{\mathrm{x}} \mathrm{CO}_{2} \mathrm{Se}_{2} \\
14 / \mathrm{mmm} \mathrm{a} \\
\mathrm{b}(\AA)\end{array}$ & $\begin{array}{l}\mathrm{K}_{\mathrm{x}} \mathrm{Co}_{2} \mathrm{Se}_{2} \\
14 / \mathrm{mmmm} \mathrm{c}\end{array}$ & \begin{tabular}{|l|}
$\mathrm{K}_{\mathrm{x}} \mathrm{Co}_{2} \mathrm{Se}_{2}$ \\
$14 / m m m$ \\
Phase \\
Fraction \\
\end{tabular} & \begin{tabular}{|l} 
March- \\
Dollase \\
Ratio
\end{tabular} & Axis & $\begin{array}{l}\mathrm{K}_{\mathrm{x}} \mathrm{Co}_{2} \mathrm{Se}_{2} \\
14 m \\
\mathrm{a}, \mathrm{b}(\AA)\end{array}$ & \begin{tabular}{|l|} 
\\
$\mathrm{K}_{\mathrm{x}} \mathrm{Co}_{2} \mathrm{Se}_{2}$ \\
$\mathrm{I4m}$ \\
$\mathrm{c}(\AA \AA \AA)$ \\
\end{tabular} & \begin{tabular}{|l|} 
\\
$\mathrm{K}_{\mathrm{x}} \mathrm{CO}_{2} \mathrm{Se}_{2}$ \\
$\mid 14 m$ \\
Phase \\
Fraction
\end{tabular} & \begin{tabular}{|l|} 
March- \\
Dollase \\
Ratio \\
\end{tabular} & Axis $P$ & $\begin{array}{l}\mathrm{K}_{\mathrm{x}} \mathrm{CO}_{2} \mathrm{Se}_{2} \\
\mathrm{P} 4 / n m m \\
\mathrm{a}, \mathrm{b}(\AA \AA)\end{array}$ & $\begin{array}{l}\mathrm{K}_{\mathrm{X}} \mathrm{CO}_{2} \mathrm{Se}_{2} \\
\mathrm{P4} / \mathrm{nmmm} \\
\mathrm{c}(\AA)\end{array}$ & $\mid \begin{array}{l}\mathrm{K}_{\mathrm{x}} \mathrm{Co}_{2} \mathrm{Se}_{2} \\
\mathrm{P} 4 / \mathrm{nmm}^{-} \\
\text {Phase } \\
\text { Fraction }\end{array}$ & $\begin{array}{l}\text { Carbon } \\
\text { Black } \\
\text { a, b }(\AA)\end{array}$ & \begin{tabular}{|l|} 
Carbon \\
Black \\
c (Å)
\end{tabular} & \begin{tabular}{|l|} 
Carbon \\
Black \\
Phase \\
Fraction \\
\end{tabular} & \begin{tabular}{|l} 
Zero \\
Offset \\
\end{tabular} & wR \\
\hline Paren & & & & & & & & & & & & & & & & & & & & & & & & & & \\
\hline $2 \%$ & 3.705 & 5.330 & $0.29(1)$ & 0.695 & 001 & 3.561 & 5.316 & $0.188(7)$ & 3.775 & 14.02 & $0.25(1)$ & 1.717 & 002 & 8.86 & 15.66 & $0.135(8)$ & 1.376 & 002 & & & & 2.72 & 6.82 & $0.13(4)-$ & -0.09229 & $2.04 \%$ \\
\hline $6 \%$ & $3.705(3)$ & $5.330(2)$ & $0.111(4)$ & 0.5687 & 001 & $3.561(6)$ & $5.316(7)$ & $0.091(4)$ & $3.775(6)$ & 14.02(3) & $0.43(2)$ & 1.409 & 002 & $8.86(4)$ & $15.66(2)$ & $0.001(2)$ & 0.9014 & 002 & & & & $2.72(3)$ & $6.82(2)$ & $0.37(3) 0$ & 0.022406 & $61.97 \%$ \\
\hline $30 \%$ & 3.699(3) & $5.31(1)$ & $0.55(4)$ & 1.5974 & 001 & & & & 3.773(3) & $14.03(1)$ & $0.24(2)$ & 0.6688 & 002 & & & & & & $3.842(3)$ & $9.32(2)$ & $0.21(1)$ & & & & 0.025385 & $53.29 \%$ \\
\hline $70 \%$ & $3.72(1)$ & $5.33(4)$ & $0.49(3)$ & 0.8561 & 001 & & & & $3.80(2)$ & 13.9(1) & $0.51(2)$ & 0.672 & 002 & & & & & & & & & & & & -0.00472 & $4.52 \%$ \\
\hline
\end{tabular}

Table S3: Rietveld refinement model parameters for CoSe versus Na ex-situ experiments. Abbreviations used are as follows. CoSe Hex: Hexagonal CoSe. CoSe Tetr: Tetragonal CoSe. a,b,c: Crystallographic Lattice parameters. wR: Weighted Residual. Cu phase fraction was 0.743(3) and $a=3.6159(2) \AA$.

\begin{tabular}{|c|c|c|c|c|c|c|c|c|c|c|c|c|c|c|c|c|c|c|c|c|}
\hline & $\begin{array}{l}\text { CoSe } \\
\text { Hex } \\
\mathrm{a}(\AA)\end{array}$ & $\begin{array}{l}\text { CoSe } \\
\text { Hex } \\
\text { b (Å) }\end{array}$ & $\begin{array}{l}\text { CoSe } \\
\text { Hex } \\
\text { c (Å) }\end{array}$ & \begin{tabular}{|l} 
CoSe \\
Hex \\
Phase \\
Fraction \\
\end{tabular} & $\begin{array}{l}\text { CoSe } \\
\text { Tetr } \\
\text { a (A) }\end{array}$ & $\begin{array}{l}\text { CoSe } \\
\text { Tetr } \\
\text { b (Å) }\end{array}$ & $\begin{array}{l}\text { CoSe } \\
\text { Tetr } \\
\text { c (̊̊) }\end{array}$ & \begin{tabular}{|l} 
CoSe \\
Tetr \\
Phase \\
Fraction \\
\end{tabular} & $\begin{array}{l}\text { March- } \\
\text { Dollase } \\
\text { Ratio }\end{array}$ & Axis & $\begin{array}{l}\mathrm{Na}_{2} \mathrm{Se} \\
\mathrm{a}(\AA)\end{array}$ & $\begin{array}{l}\mathrm{Na}_{2} \mathrm{Se} \\
\mathrm{b}(\mathrm{A})\end{array}$ & $\begin{array}{l}\mathrm{Na}_{2} \mathrm{Se} \\
\mathrm{c}(\hat{\mathrm{A}})\end{array}$ & $\begin{array}{l}\mathrm{Na}_{2} \mathrm{Se} \\
\text { Phase } \\
\text { Fraction }\end{array}$ & $\begin{array}{l}\mathrm{Na}_{2} \mathrm{Se}_{2} \\
\mathrm{a}(\hat{\mathrm{A}})\end{array}$ & $\begin{array}{l}\mathrm{Na}_{2} \mathrm{Se}_{2} \\
\mathrm{~b}(\AA \AA \\
\mathrm{A})\end{array}$ & $\begin{array}{l}\mathrm{Na}_{2} \mathrm{Se}_{2} \\
\mathrm{c}(\AA)\end{array}$ & $\begin{array}{l}\mathrm{Na}_{2} \mathrm{Se}_{2} \\
\text { Phase } \\
\text { Fraction }\end{array}$ & wR & \begin{tabular}{|l} 
Zero \\
Offset
\end{tabular} \\
\hline Parent & & & & & & & & & & & & & & & & & & & & \\
\hline $2 \%$ & $3.588(9)$ & $3.588(9)$ & $5.31(1)$ & $0.320(1)$ & $3.709(3)$ & $3.709(3)$ & $5.337(7)$ & $0.680(1)$ & 0.7969 & |001 & & & & & & & & & $2.16 \%$ & 0.111567 \\
\hline $5 \%$ & $3.608(6)$ & $3.608(6)$ & $5.251(7)$ & $0.050(3)$ & $3.701(6)$ & $3.701(6)$ & $5.343(4)$ & $0.207(6)$ & 0.6172 & 001 & & & & & & & & & $3.54 \%$ & 0.036906 \\
\hline $50 \%$ & & & & & & & & & & & $6.78(2)$ & $6.78(2)$ & $6.78(2)$ & $44.0(2) \%$ & $4.74(7)$ & $4.74(7)$ & $10.47(3)$ & $56.0(2) \%$ & $2.29 \%$ & -0.11216 \\
\hline $100 \%$ & & & & & & & & & & & $6.809(4)$ & $6.809(4)$ & $6.806(4)$ & $100 \%$ & $5.0(2)$ & $5.0(2)$ & $11.15(1)$ & $0.31(1)$ & $4.72 \%$ & -0.05812 \\
\hline
\end{tabular}




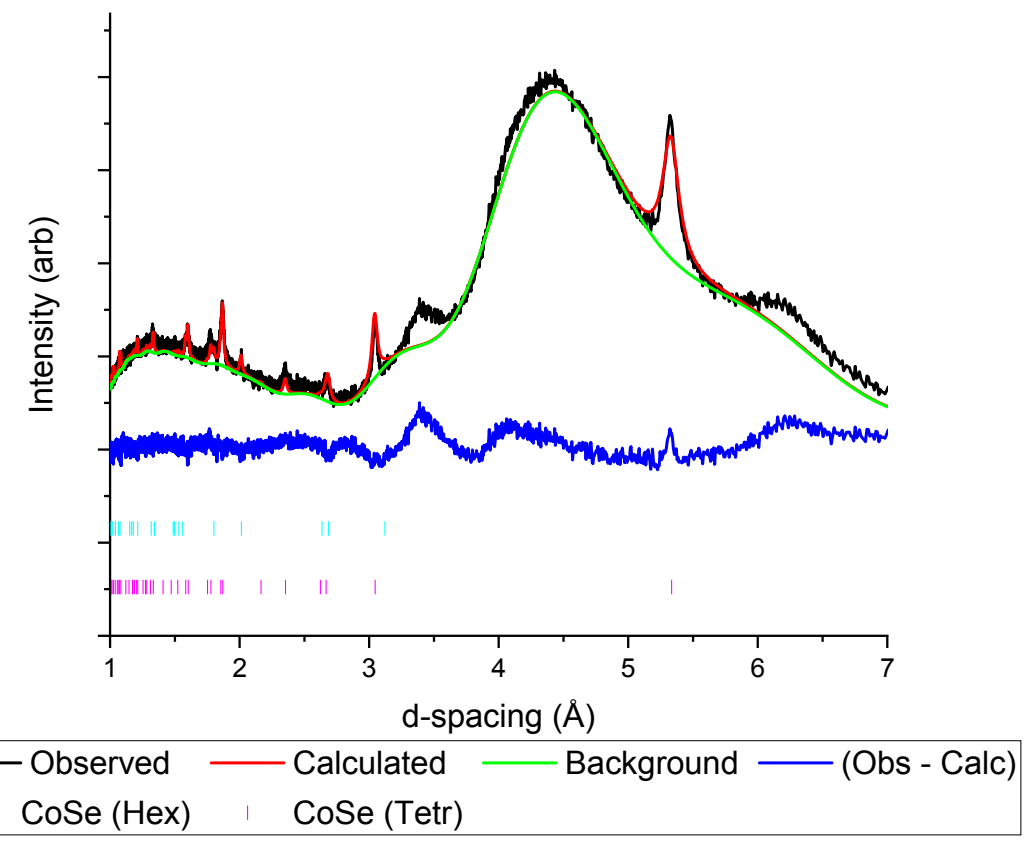

Figure S1: Rietveld analysis of structural models with PXRD data from the CoSe electrode.

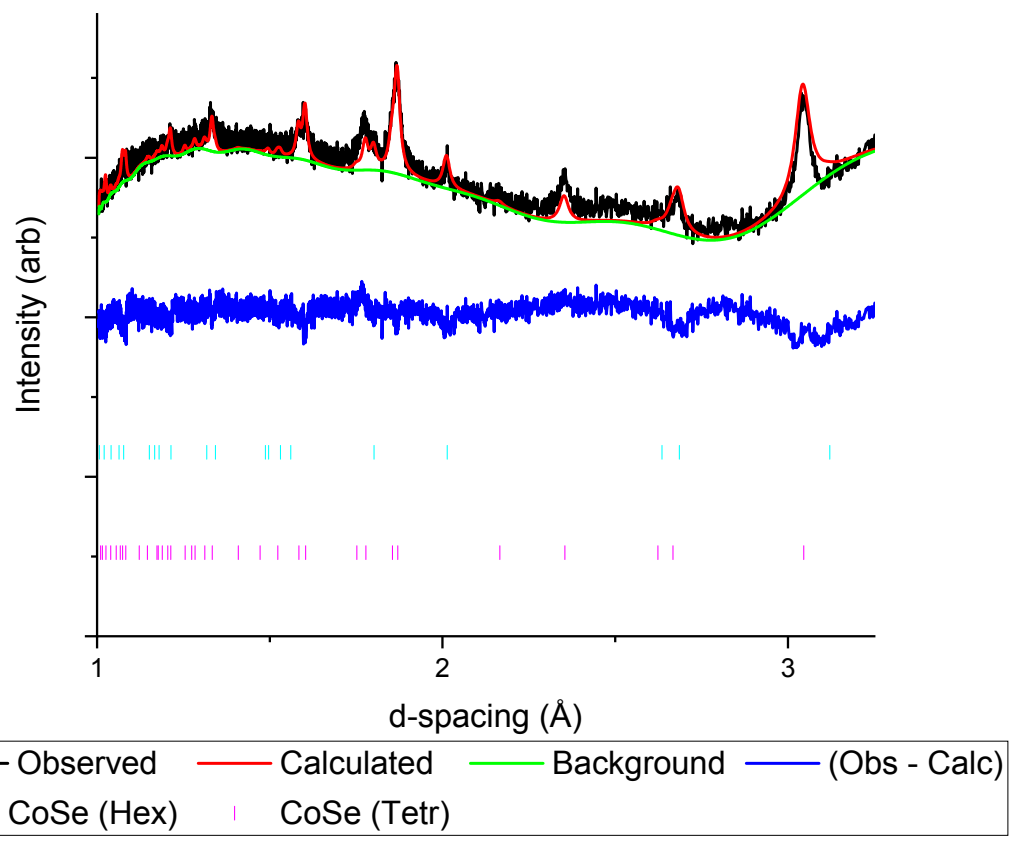

Figure S2: Rietveld analysis of structural models with PXRD data from the CoSe electrode, zoomed to a region of interest. 


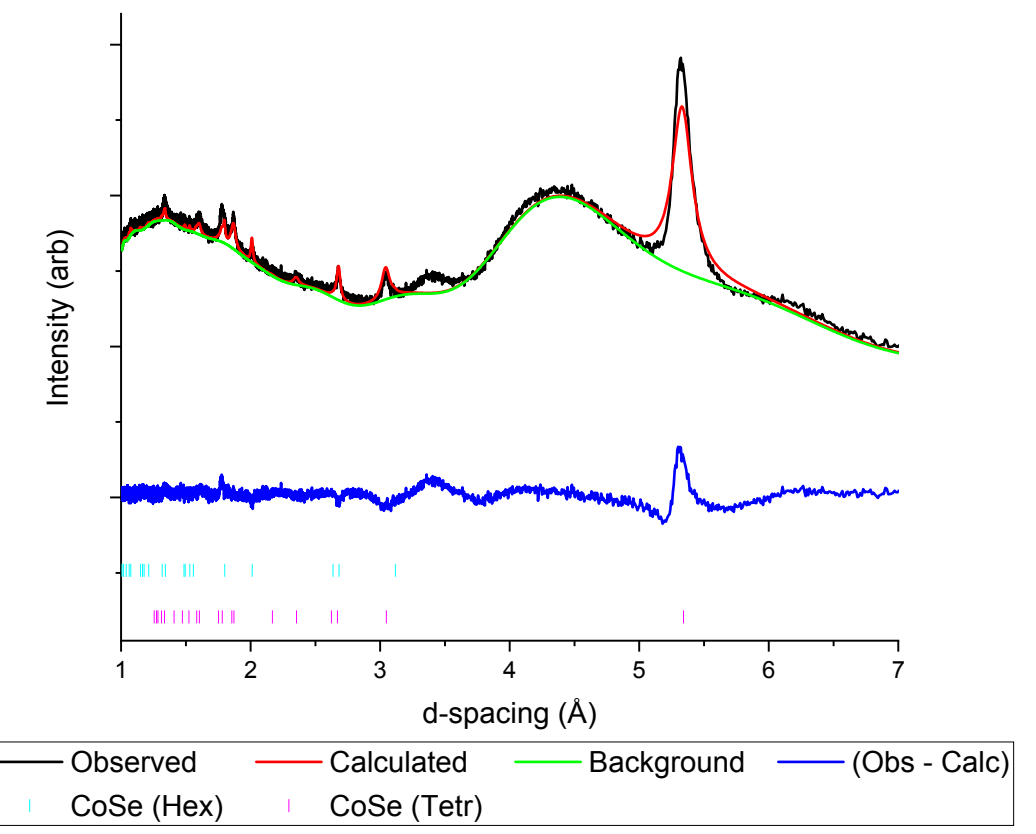

Figure S3: Rietveld analysis of structural models with PXRD data of an electrode extracted from a CoSe versus Li half cell discharged to $3 \%$ of full capacity.

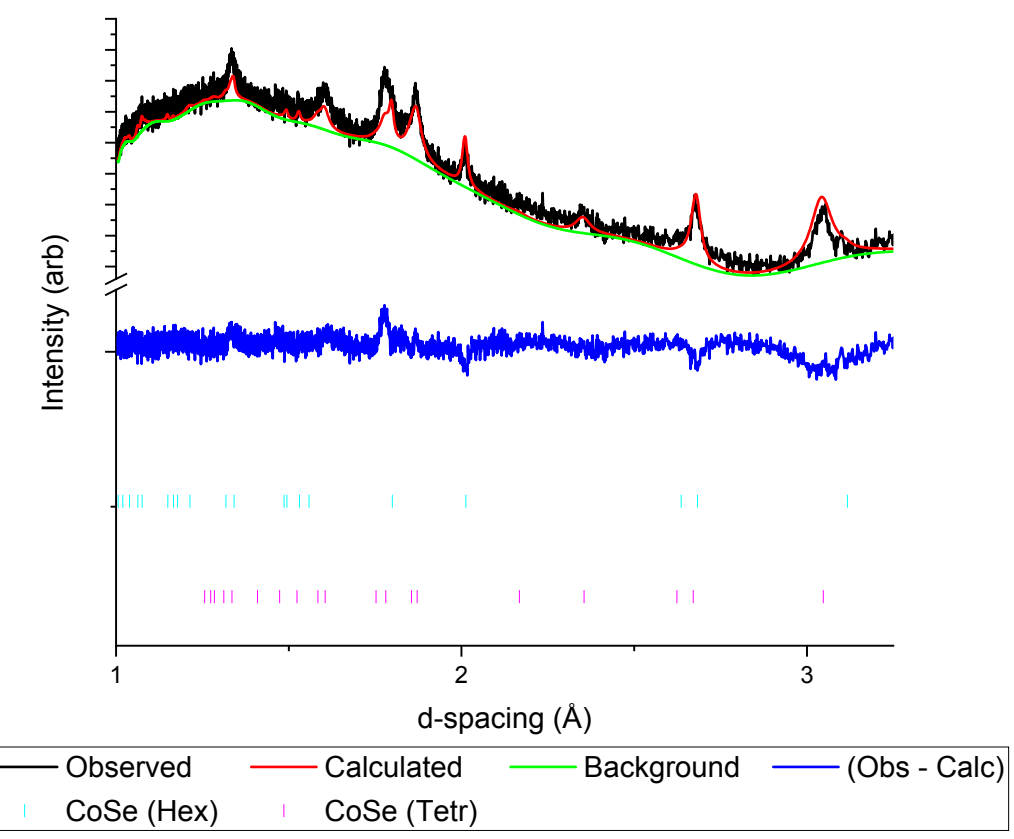

Figure S4: Rietveld analysis of structural models with PXRD data of an electrode extracted from a CoSe versus Li half cell discharged to $3 \%$ of full capacity, zoomed to show region of interest. 


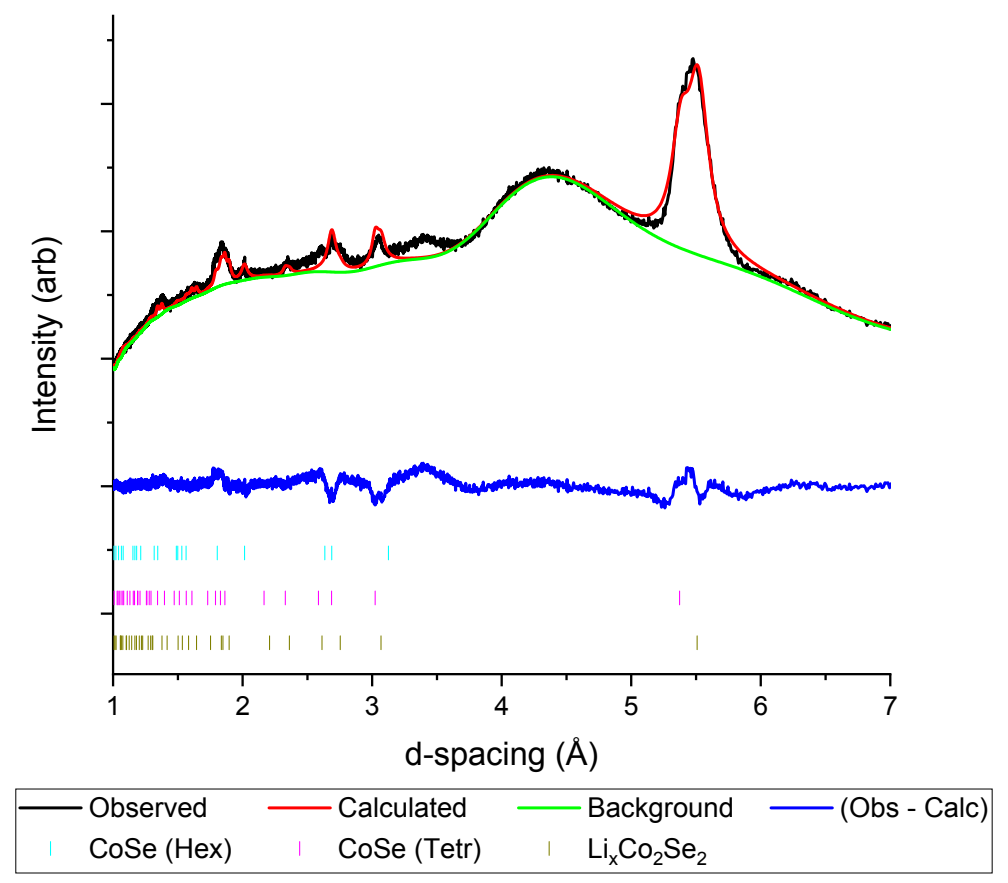

Figure S5: Rietveld analysis of structural models with PXRD data of an electrode extracted from a CoSe versus Li half cell discharged to $7.5 \%$ of full capacity.

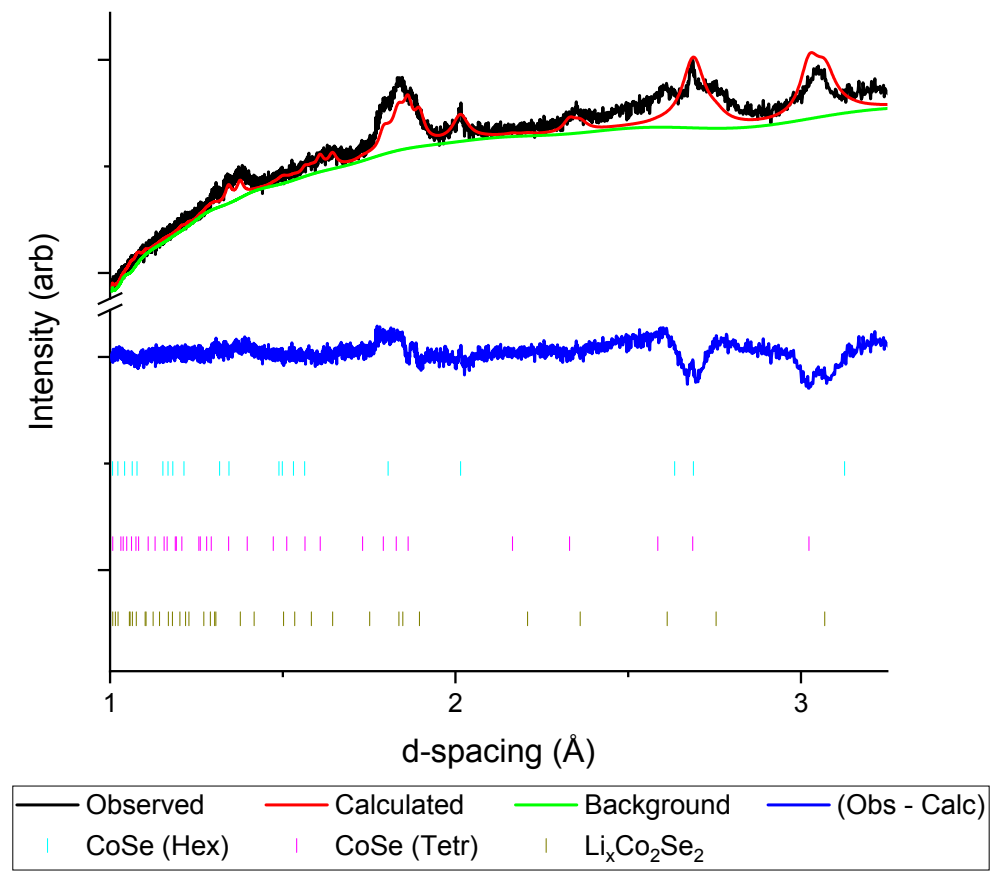

Figure S6: Rietveld analysis of structural models with PXRD data of an electrode extracted from a CoSe versus Li half cell discharged to $7.5 \%$ of full capacity, zoomed to show region of interest. 


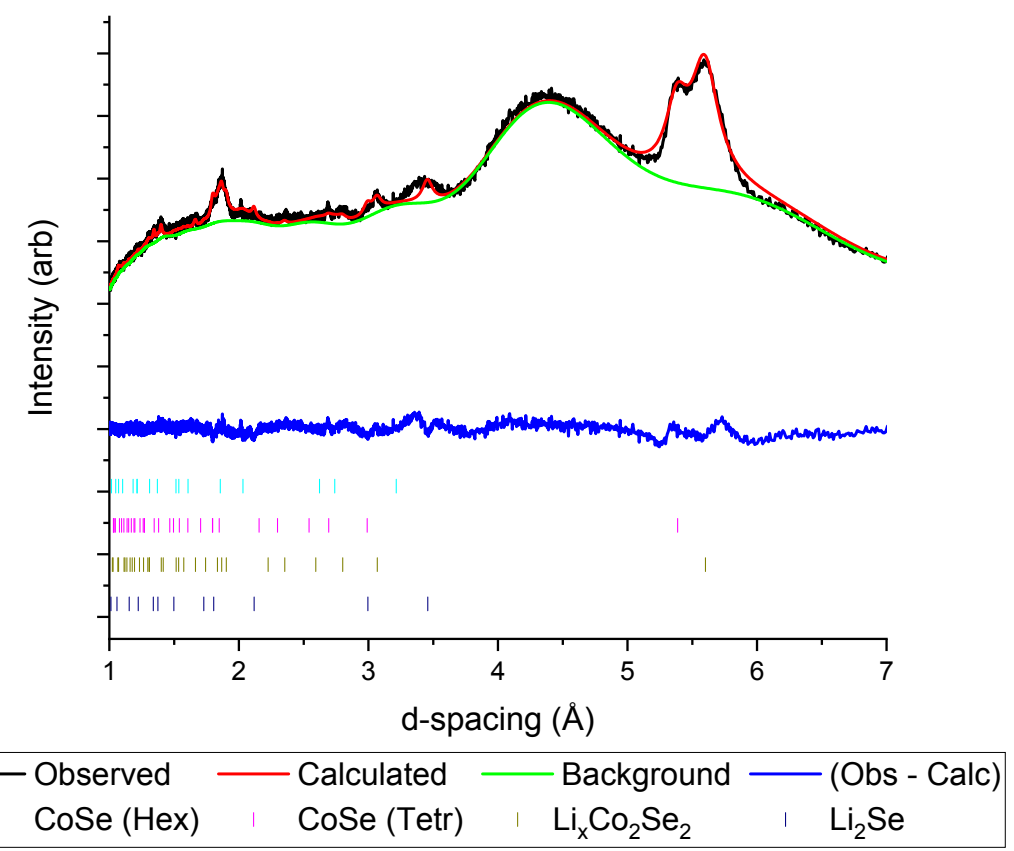

Figure S7: Rietveld analysis of structural models with PXRD data of an electrode extracted from a CoSe versus Li half cell discharged to $20 \%$ of full capacity.

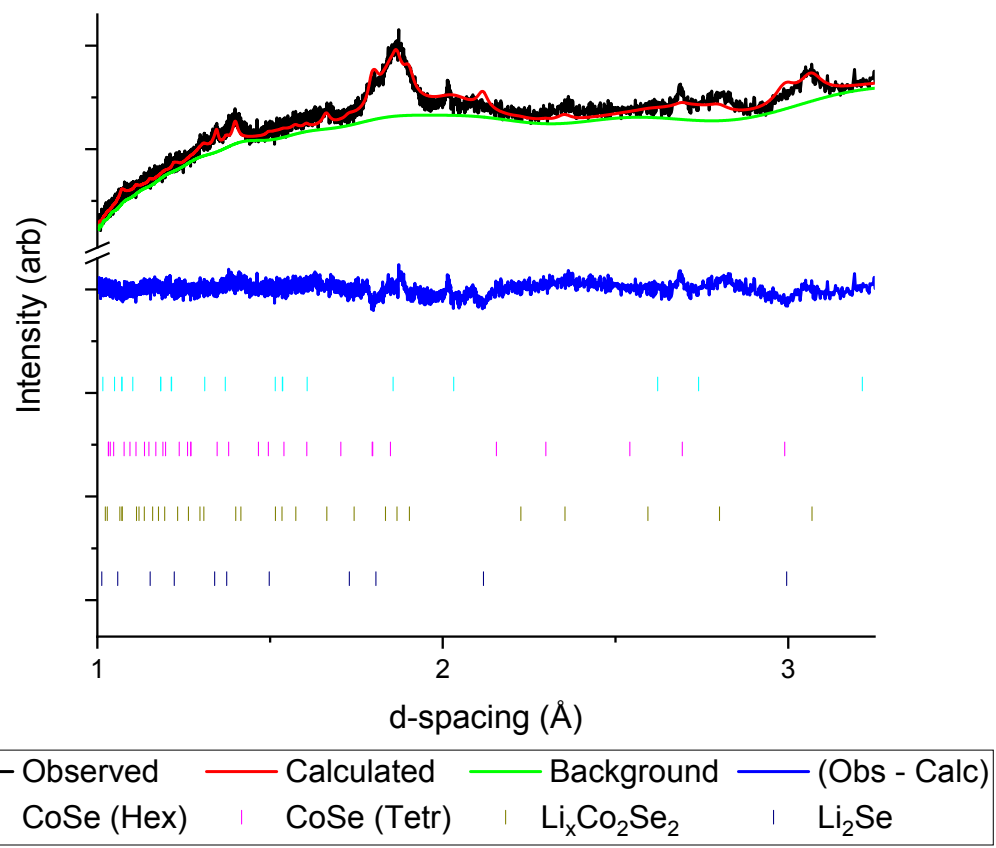

Figure S8: Rietveld analysis of structural models with PXRD data of an electrode extracted from a CoSe versus Li half cell discharged to $20 \%$ of full capacity, zoomed to show region of interest. 


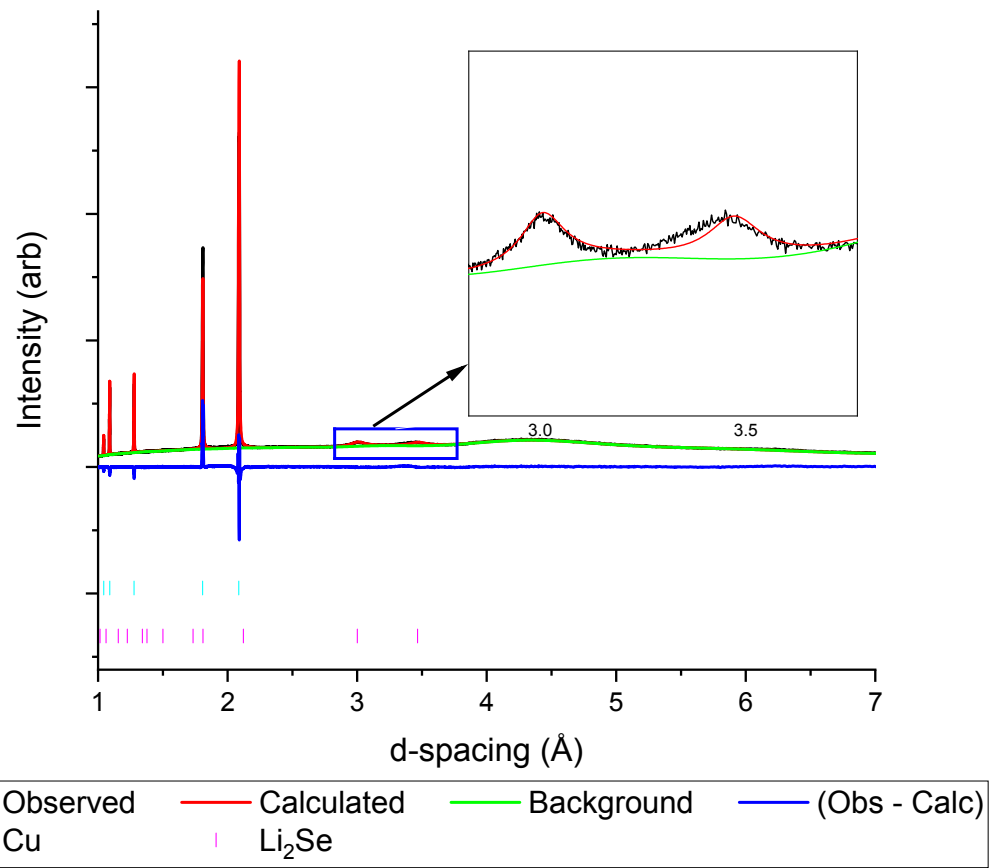

Figure S9: Rietveld analysis of structural models with PXRD data of an electrode extracted from a CoSe versus Li half cell discharged to $60 \%$ of full capacity.

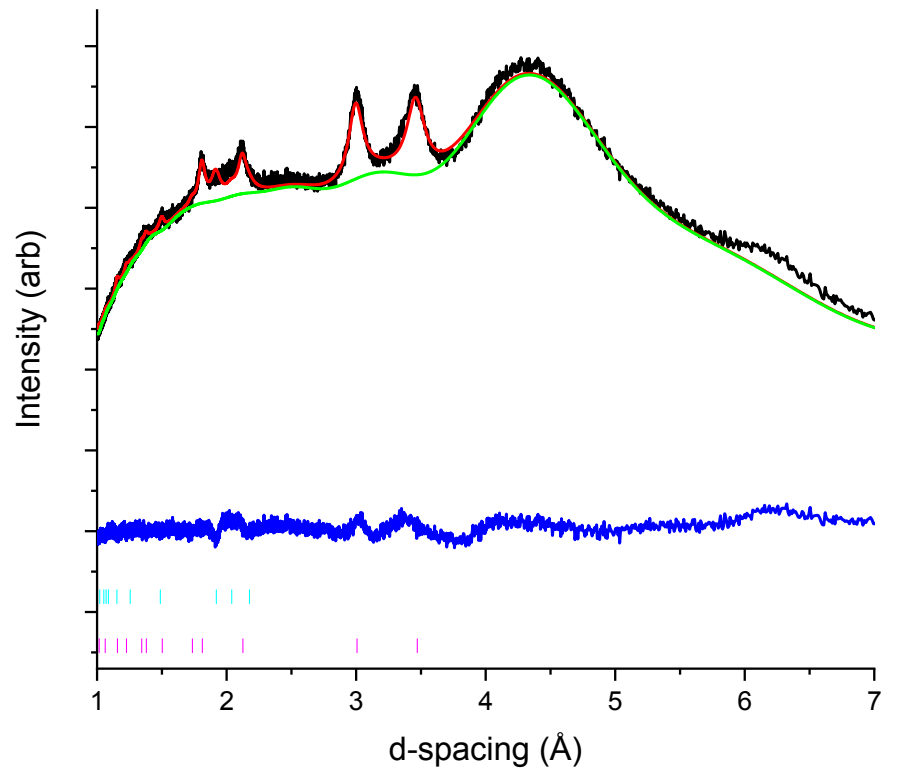

\begin{tabular}{|ll}
- Observed & Calculated \\
Co & $\mathrm{Li}_{2} \mathrm{Se}$
\end{tabular}$-$ Background - (Obs - Calc)

Figure S10: Rietveld analysis of structural models with PXRD data of an electrode extracted from a CoSe versus Li half cell discharged to $100 \%$ of full capacity. 


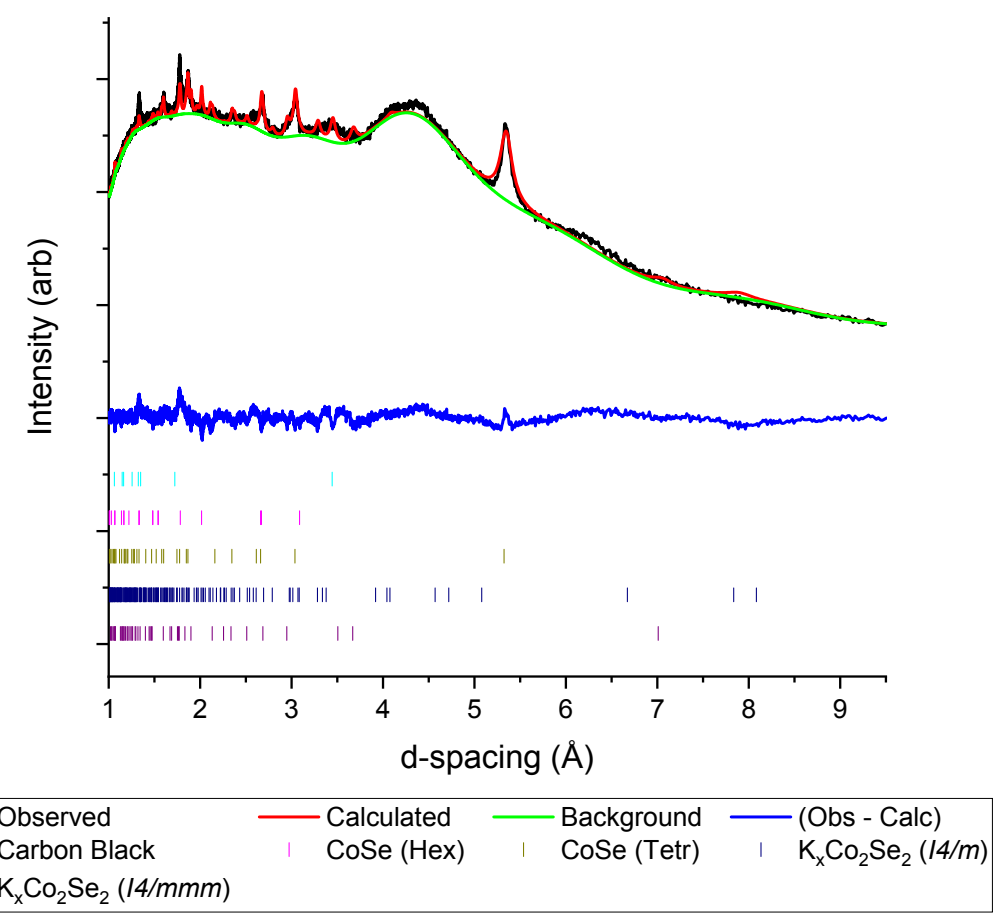

Figure S11: Rietveld analysis of structural models with PXRD data of an electrode extracted from a CoSe versus $\mathrm{K}$ half cell discharged to $2 \%$ of full capacity.

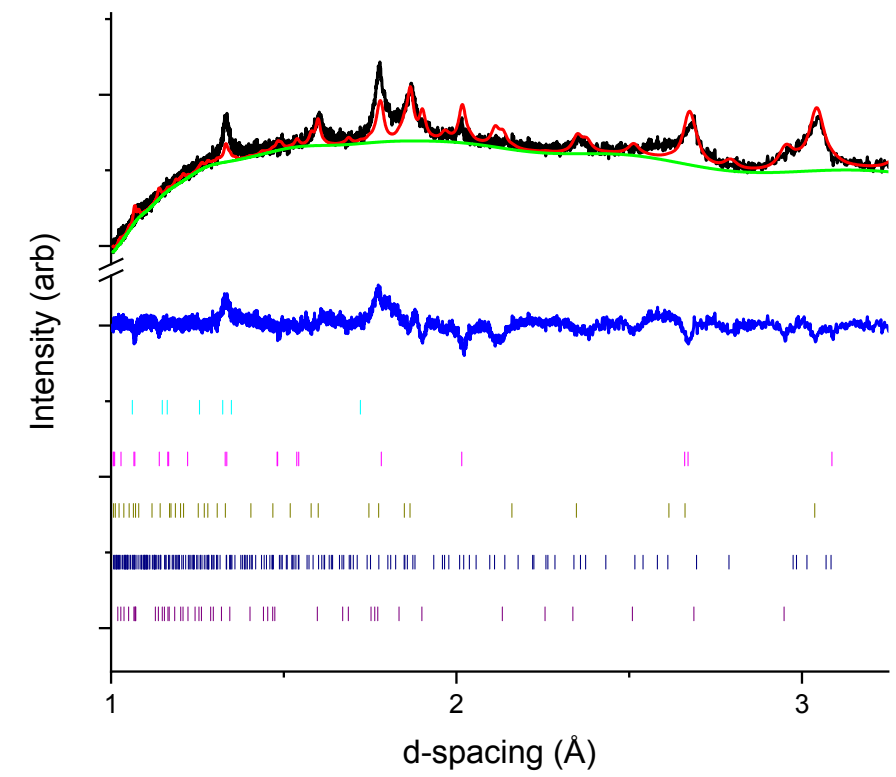

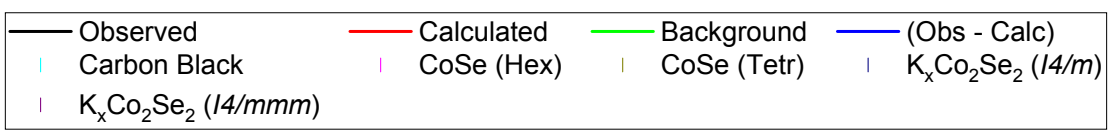

Figure S12: Rietveld analysis of structural models PXRD data of an electrode extracted from a CoSe versus $\mathrm{K}$ half cell discharged to $2 \%$ of full capacity, zoomed to region of interest. 


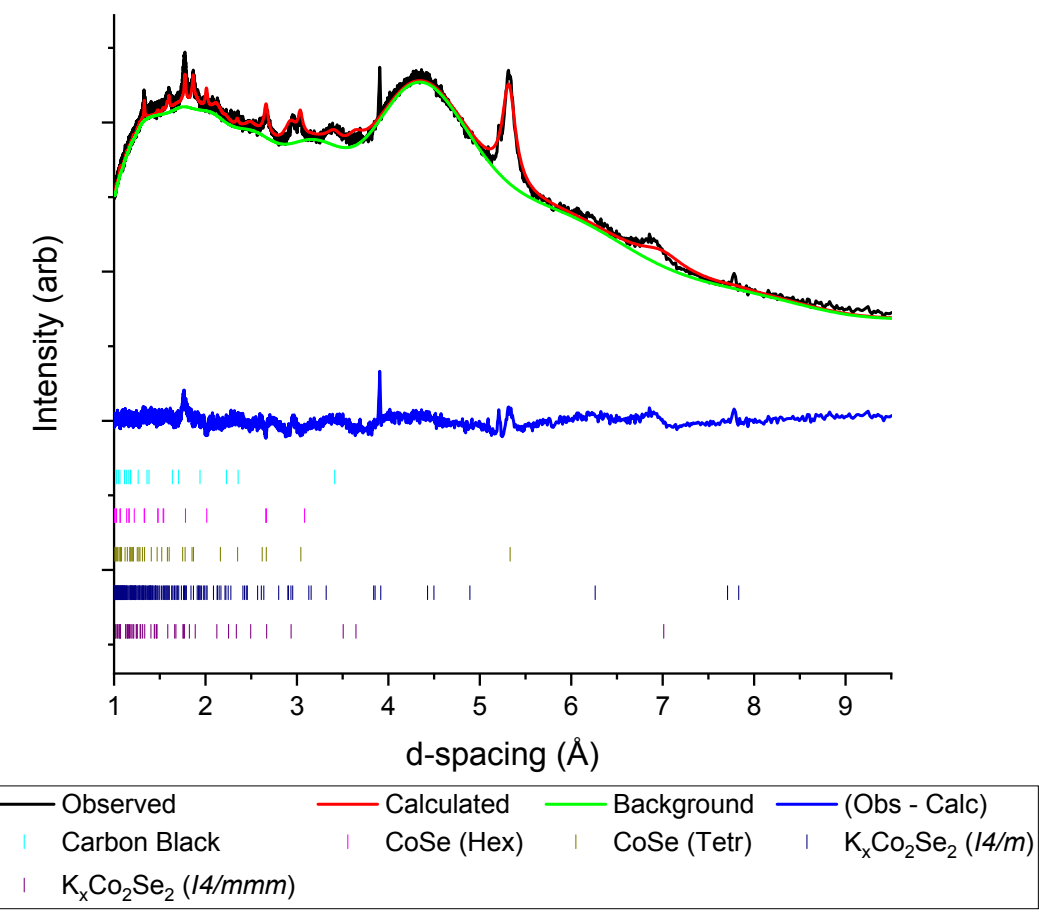

Figure S13: Rietveld analysis of structural models with PXRD data of an electrode extracted from a CoSe versus $\mathrm{K}$ half cell discharged to $6 \%$ of full capacity.

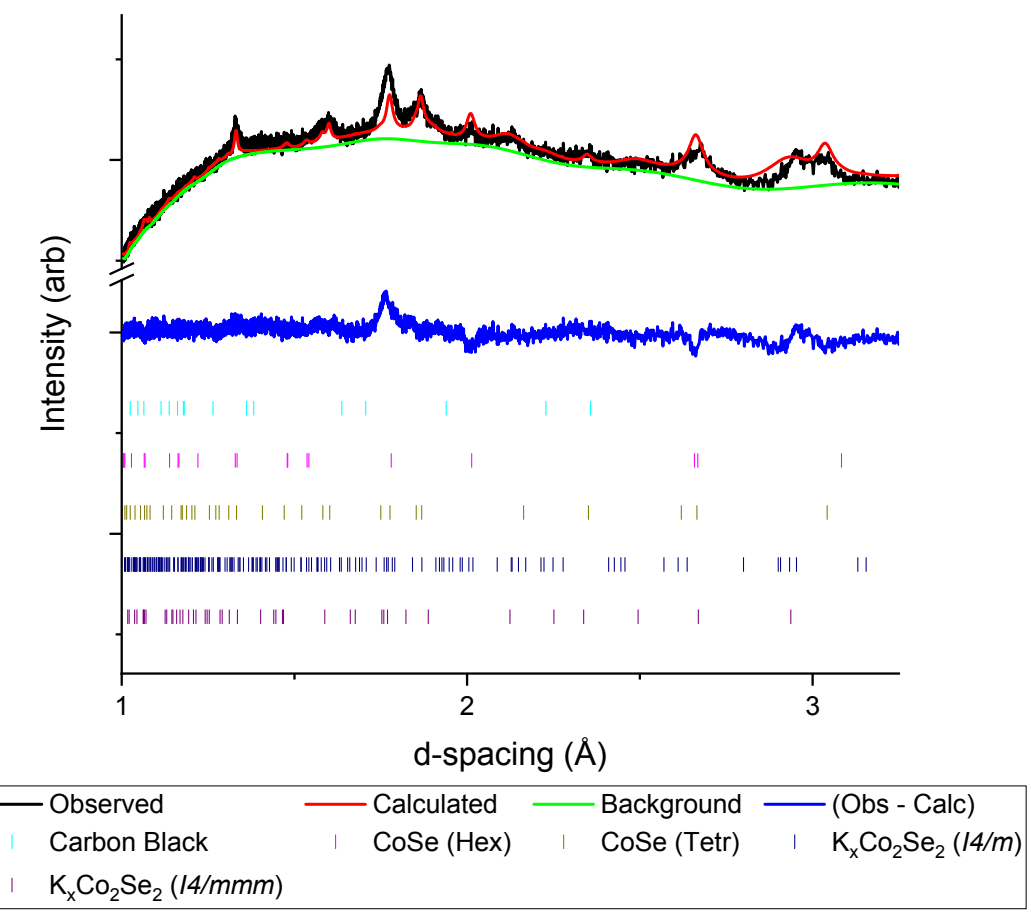

Figure S14: Rietveld analysis of structural models with PXRD data of an electrode extracted from a CoSe versus $\mathrm{K}$ half cell discharged to $6 \%$ of full capacity, zoomed to region of interest. 


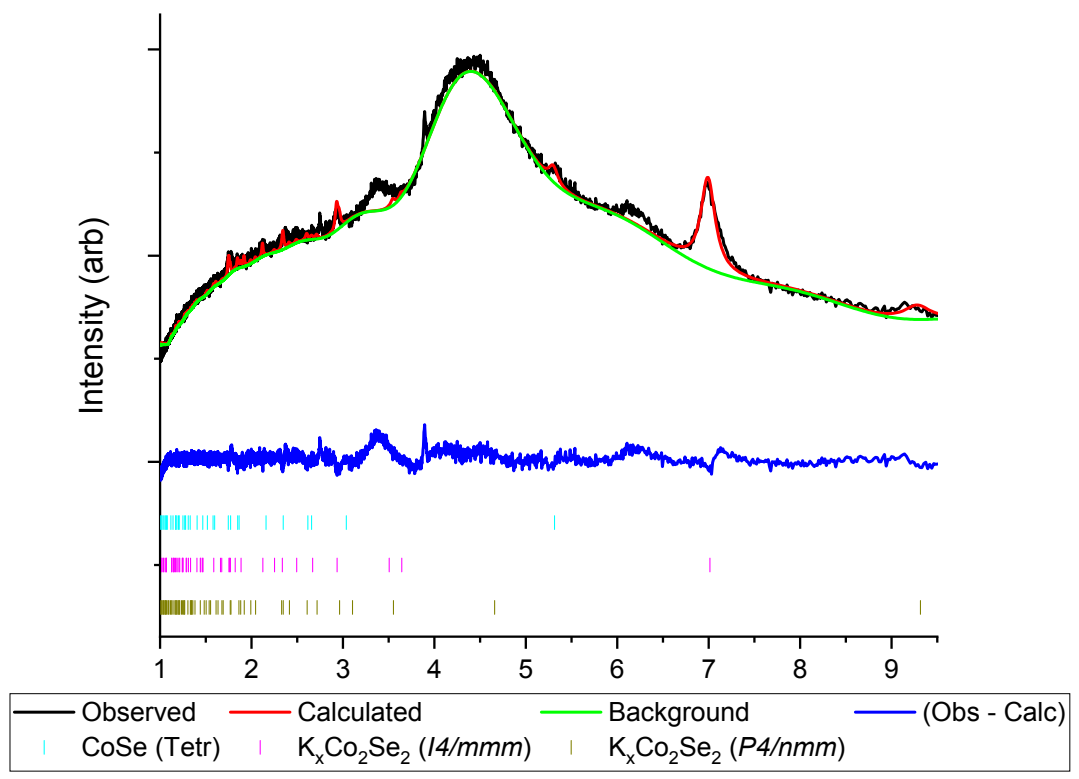

Figure S15: Rietveld analysis of structural models with PXRD data of an electrode extracted from a CoSe versus $\mathrm{K}$ half cell discharged to $30 \%$ of full capacity.

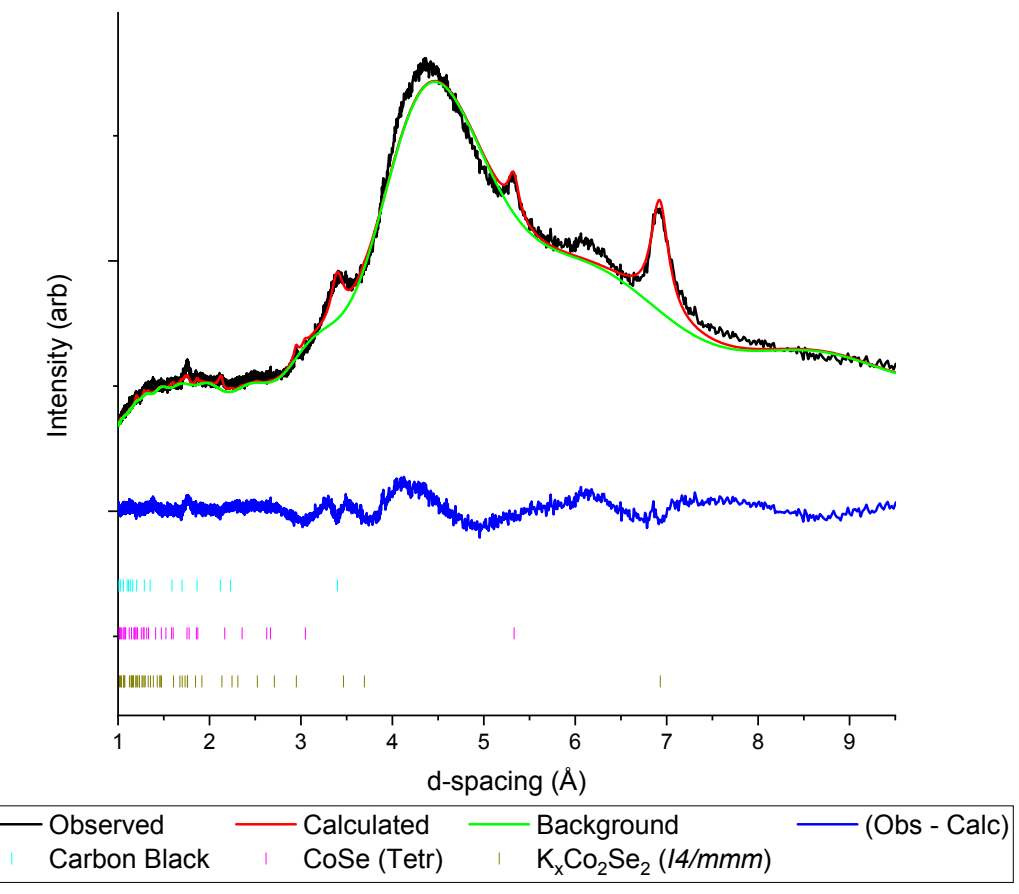

Figure S16: Rietveld analysis of structural models with PXRD data of an electrode extracted from a CoSe versus $\mathrm{K}$ half cell discharged to $70 \%$ of full capacity. 


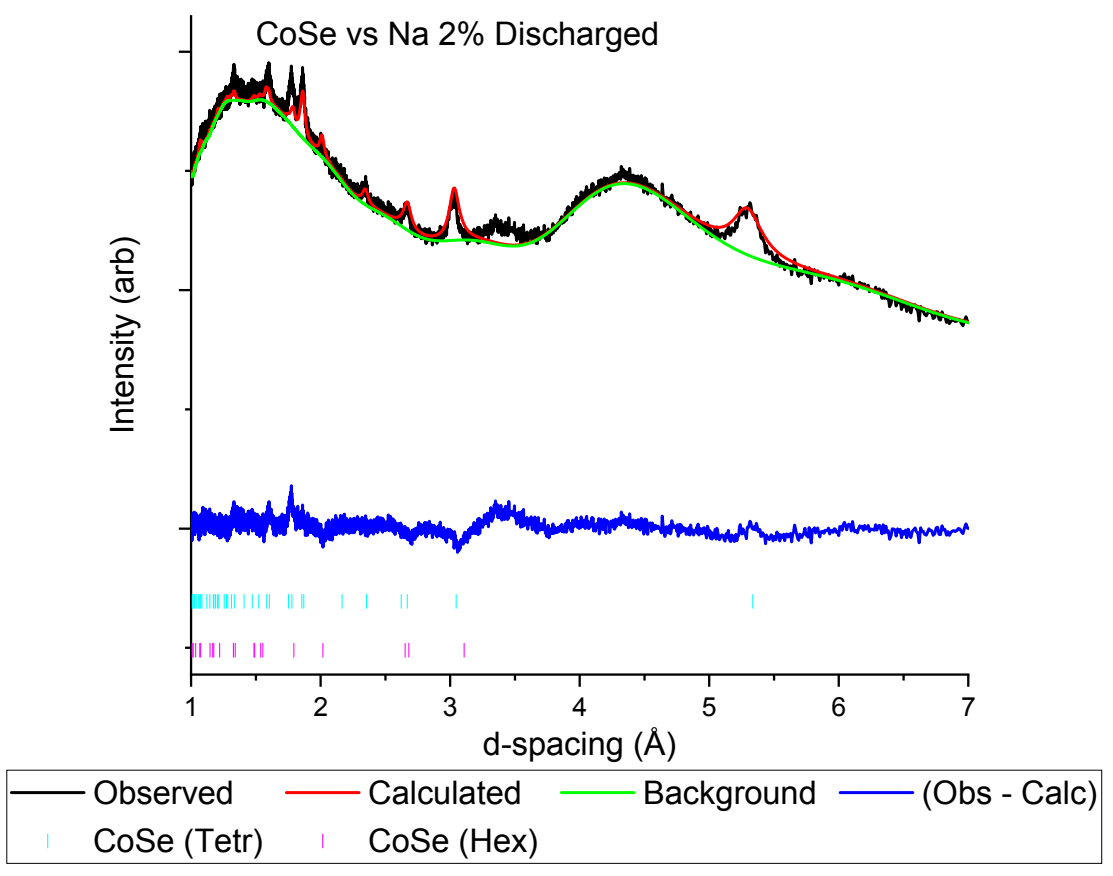

Figure S17: Rietveld analysis of structural models with PXRD data of an electrode extracted from a CoSe versus $\mathrm{Na}$ half cell discharged to $2 \%$ of full capacity.

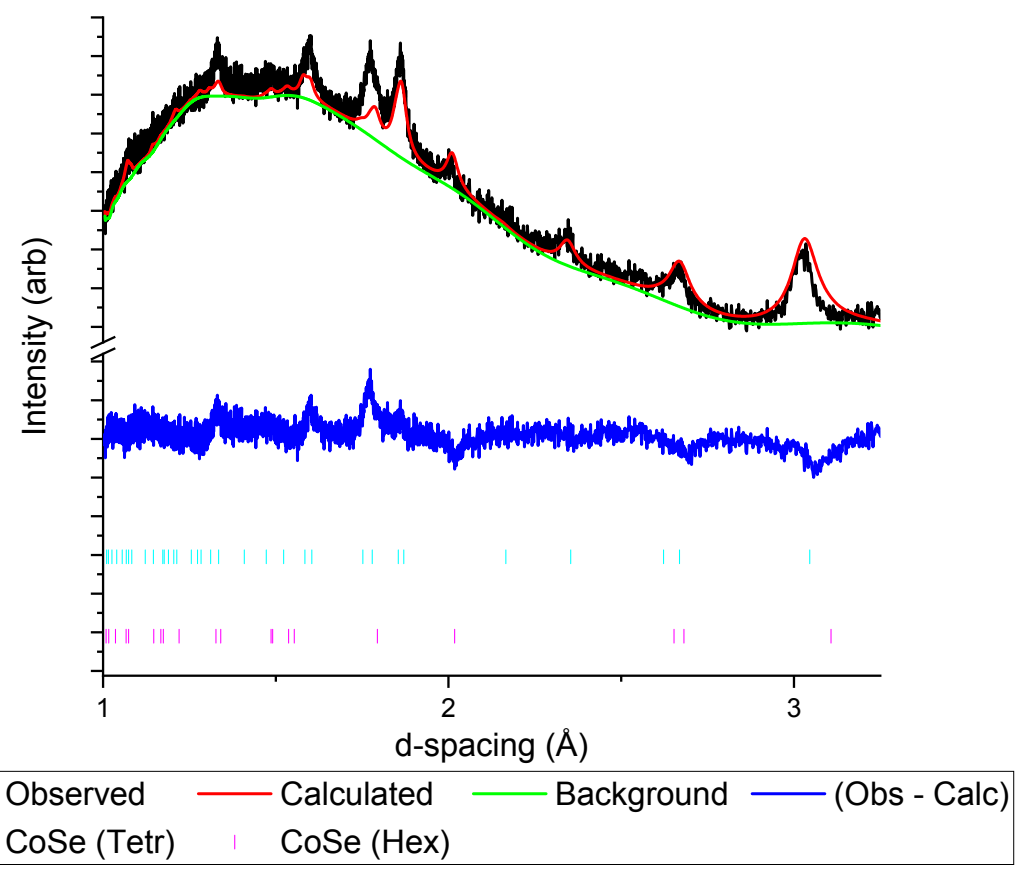

Figure S18: Rietveld analysis of structural models with PXRD data of an electrode extracted from a CoSe versus $\mathrm{Na}$ half cell discharged to $2 \%$ of full capacity, zoomed to region of interest. 


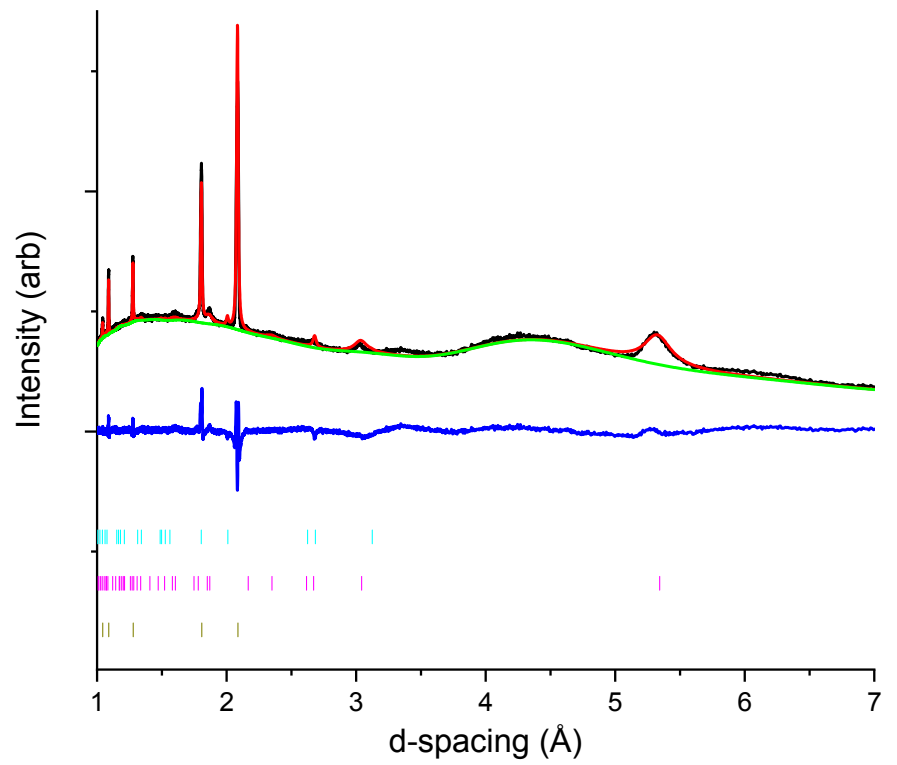

\begin{tabular}{|lll|}
\hline Observed & Calculated & Background - (Obs - Calc) \\
CoSe (Hex $)$ & CoSe (Tetr) & $\mathrm{Cu}$
\end{tabular}

Figure S19: Rietveld analysis of structural models with PXRD data of an electrode extracted from a CoSe versus $\mathrm{Na}$ half cell discharged to $5 \%$ of full capacity.

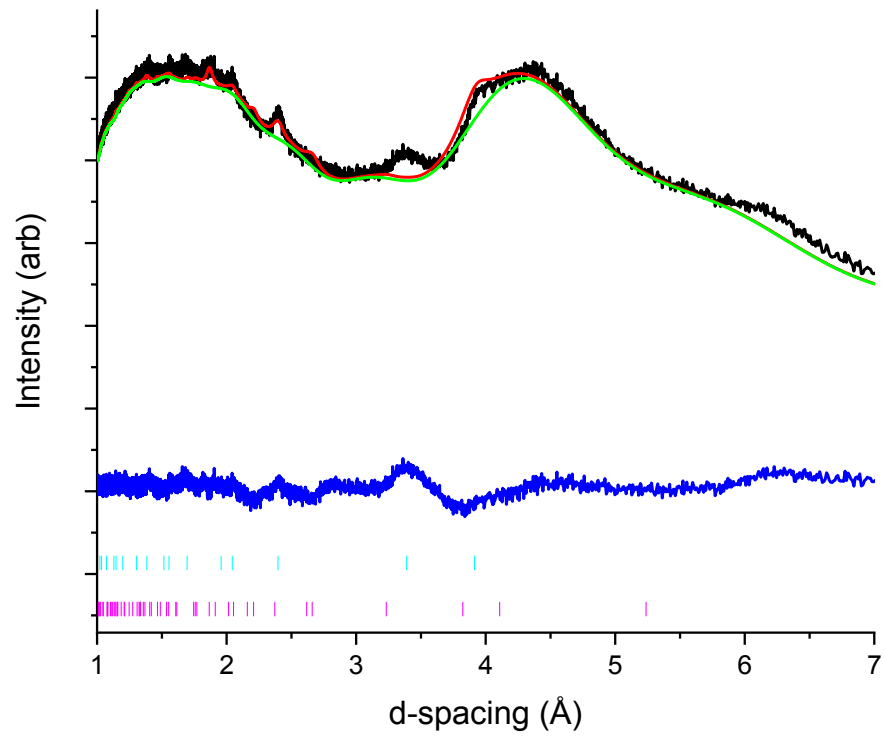

\begin{tabular}{ccc|}
- Observed & Calculated \\
$\mathrm{Na}_{2} \mathrm{Se}$ & $\mathrm{Na}_{2} \mathrm{Se}_{2}$
\end{tabular}

Figure S20: Rietveld analysis of structural models with PXRD data of an electrode extracted from a CoSe versus $\mathrm{Na}$ half cell discharged to $50 \%$ of full capacity. 


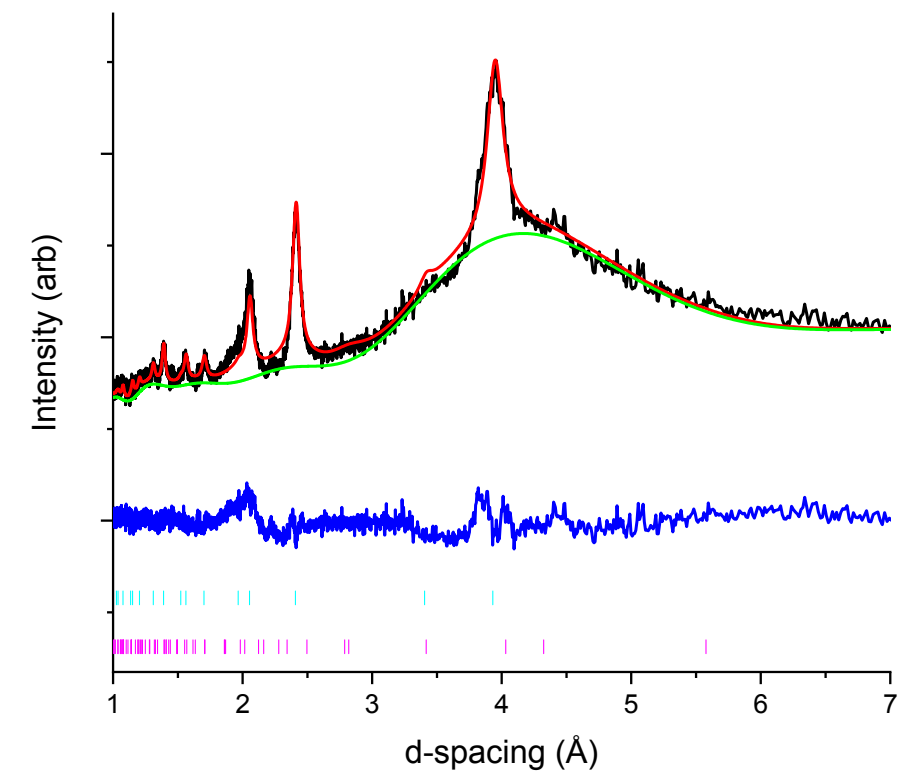

$\begin{gathered}- \text { Observed } \\ \mathrm{Na}_{2} \mathrm{Se}\end{gathered}-$ Calculated - Background - (Obs - Calc)

Figure S21: Rietveld analysis of structural models with PXRD data of an electrode extracted from a CoSe versus $\mathrm{Na}$ half cell discharged to $100 \%$ of full capacity.

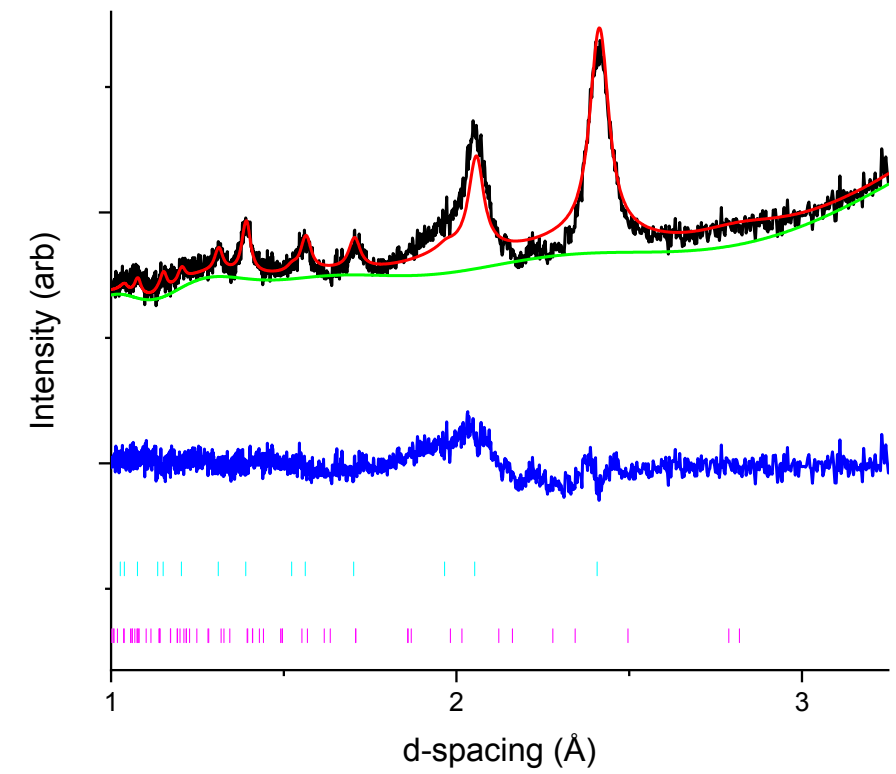

$\begin{gathered}\text { Observed } \\ \mathrm{Na}_{2} \mathrm{Se}\end{gathered}-$ Calculated - Background - (Obs - Calc)

Figure S22: Rietveld analysis of structural models with PXRD data of an electrode extracted from a CoSe versus $\mathrm{Na}$ half cell discharged to $100 \%$ of full capacity, zoomed to region of interest. 


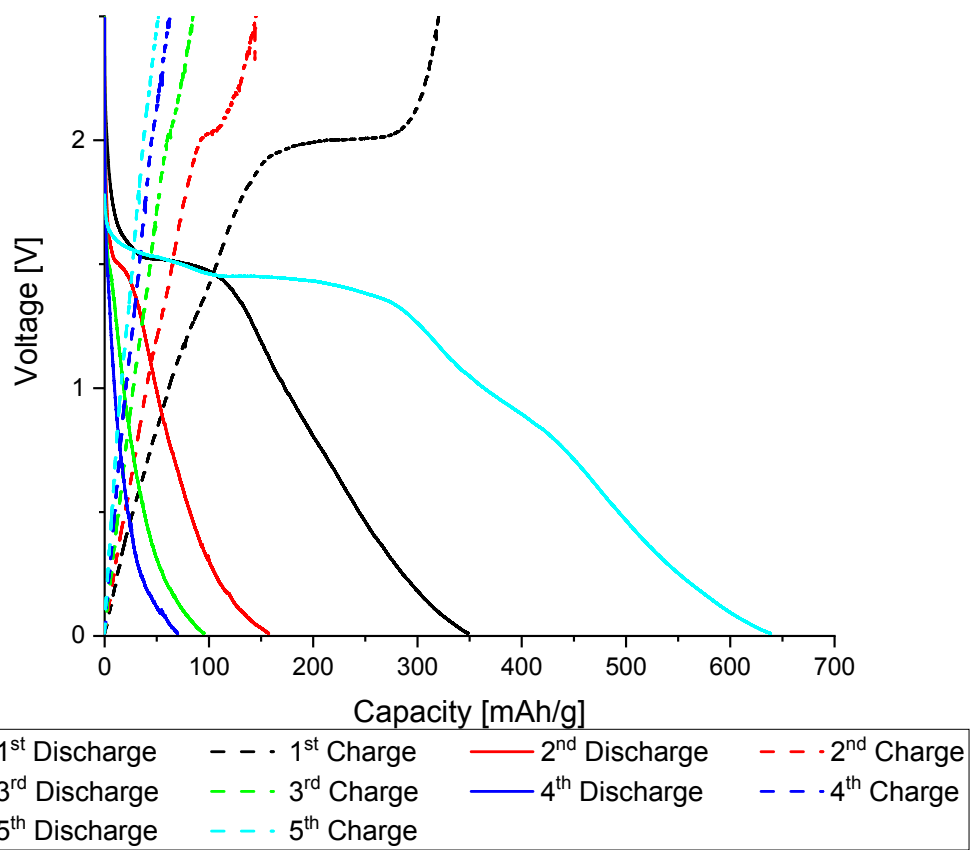

Figure S23: Capacity-voltage curves of CoSe versus Li cell, cycled (discharged, then charged) 5 times.

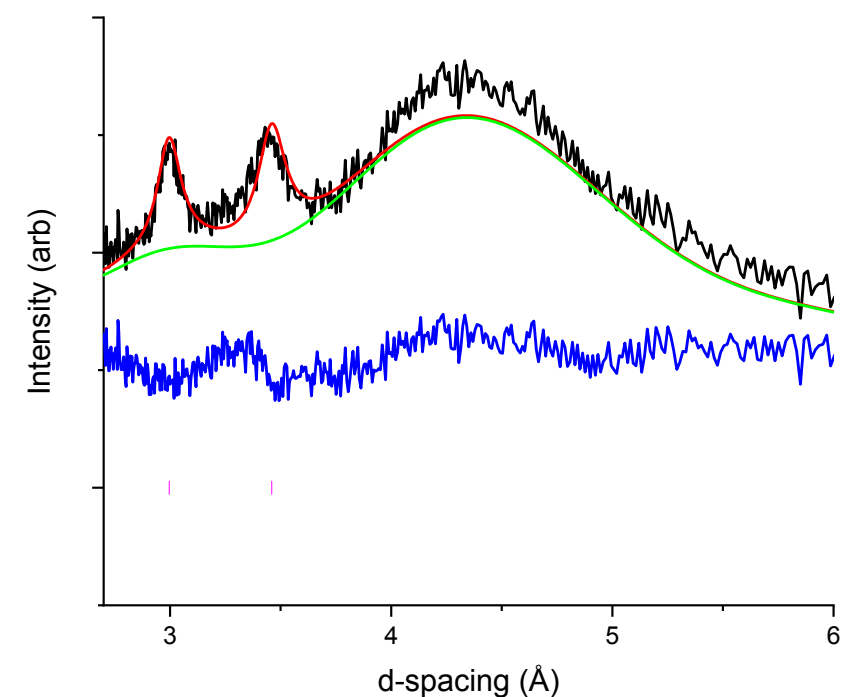

Observed - Calculated - Background - (Obs - Calc)
$\mathrm{Li}_{2} \mathrm{Se}$

Figure S24: Rietveld analysis of structural models with PXRD data collected from CoSe versus Li sample, cycled (discharged, then charged) 5 times. 